\title{
The Influence of the Emotional Intelligence on Self-Regulation of Aggressive Behavior among Adolescents with Disorders of Mental Development
}

\section{Вплив емоційного інтелекту на саморегуляцію агресивної поведінки підлітків із порушеннями розумового розвитку}

\author{
Olha Vovchenko \\ Ph.D. in Psychology, Doctoral Student, Mykola Yarmachenko \\ Institute of Special Pedagogy and Psychology of the National Aca- \\ demy of Educational Sciences of Ukraine, Kyiv (Ukraine) \\ ORCID ID: https://orcid.org/0000-0002-4399-0118 \\ Researcher ID: P-9297-2016 \\ E-mail: olgawow4enko@gmail.com
}

\section{Ольга Вовченко}

Кандидат психологічних наук, докторант, Інститут спеціальної педагогіки та психології ім. М. Ярмаченка Національної академії педагогічних наук України, м. Київ (Україна)

\section{ABSTRACT}

The aim of the research is to determine the problem of manifestations of aggression of adolescents with disorders of mental development in the context of the formation and influence of emotional intelligence on the aggressive behavior of these adolescents. The purpose of the research was provided by a step-by-step solution of the main tasks: firstly, to identify the features of aggression of adolescents with intellectual disabilities; secondly, to determine

Address for correspondence, e-mail: kpnu_lab_ps@ukr.net Copyright: (C) Vovchenko Olha

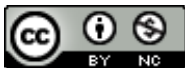

The article is licensed under CC BY-NC 4.0 International

(https://creativecommons.org/licenses/by-nc/4.0/)

(C) Vovchenko Olha

DOI (article): https://doi.org/10.32626/2227-6246.2020-49.11-36 
the specific influence of emotional intelligence on self-regulation of aggressive behavior of adolescents with intellectual disabilities; thirdly, to characterize recommendations for the technology of psychological support for the formation of self-regulation of aggressive behavior of adolescents with disorders of mental development in the context of their emotional intelligence.

Methods. The general scientific deductive and inductive methods, the method of psychological diagnostics, conversations and observations were used to solve the outlined tasks and to prove the results and make the conclusions of our research. Psychodiagnostic procedure of the state of aggressive behavior and its emotional self-regulation of adolescents with disorders of mental development was carried out using the method of "Bass and Darcy's Aggression Questionnaire»; method of "Adapted Leonhard - Shmishek's Characterological Questionnaire»; Emotional Intellect (by N. Holl) techniques, conversations and observations. In the course of psychodiagnostics, the necessary instructions and requirements were obtained to have reliable results. The interviews were conducted in the process ofstudying of adolescents at educational establishments. The behavior of adolescents was monitored in their usual learning environment. For the purpose of providing comparative analysis of the phenomenon of selfregulation of aggressive behavior of adolescence and making reliability of the results, the diagnostics of adolescents with preserved intelligence was carried out, keeping the identical procedures, under equal conditions, which were created for adolescents with disorders of mental development as well.

The results of the research. According to the results of the diagnostics, adolescents with disorders of mental development have physical and verbal aggression that exceeds the allowable norm. The diagnostics of adolescents with disorders of mental development made it possible to ascertain the functioning status of the structural components of aggression. The increased level was set up by indicators of negativity and irritability. The results of the diagnostics of adolescents with preserved intellectual state the similarity of the obtained data on the level of expressiveness of the main types of aggression and structural components of the phenomenon in comparison with the results of adolescents with disorders of mental development. The difference is the intensity of the proposed indicators. The adolescents with intellectual disabilities have indicators which are in a great degree displayed in a group of 20-30\% than in a group of respondents with preserved intellectual function. It is established that manifestations of aggression and self-regulation of aggressive behavior are determined by personality's accentuations. In a case of adolescents with disorders (c) Vovchenko Olha

DOI (article): https://doi.org/10.32626/2227-6246.2020-49.11-36 
of mental development, the following types of combination of accentuation were found to be hypertensive in combination with cyclothymic, hypertensive with unbalanced, hypertensive with exalted. In addition, adolescents with disorders of mental development have a low level of emotional intelligence, emotional awareness, empathy, managing personal emotions and an average level of ability to recognize other people's emotions.

Conclusions. The results of our research suggested that the alexithymic manifestations in the structure of the personality of adolescents with disorders of mental development were mainly due to the inability to verbalize their own emotional states, underdevelopment of the reflexive component of emotions and lack of formation or a low level of emotional intelligence. Taking into account the obtained results, the main aspects of psycho-corrective work with adolescents with disorders of mental development regarding the formation of self-regulation of aggressive behavior were characterized. This psycho-corrective work has the aim to form the ability to develop pupils' emotions, feelings and experience, to designate them with appropriate verbal symbols, to manage different emotional states, including negative ones, such as aggression and anger.

Key words: adolescence, disorders of mental development, accentuation of character, self-regulation, aggression, aggressive behavior, emotional intelligence.

\section{Вступ}

Проблема агресивної поведінки підлітків із порушеннями розумового розвитку є вкрай актуальною у контексті динамічних соціокультурних та економічних суспільних змін, оптимальне вирішення якої передбачає інтеграцію наукових підходів і прикладних стратегій. Особливої уваги потребує вирішення проблеми формування у таких підлітків емоційного інтелекту з метою мінімізації агресивних станів і формування саморегуляції поведінки підлітків із порушеннями розумового розвитку.

Актуальність дослідження агресії визначається ще й тим, яке значення мають негативні наслідки агресивної дії як для людини зокрема, так і для суспільства загалом. У зв’язку з тим, що за останні роки в країні зросла кількість осіб із порушеннями розумового та психофізичного розвит-

C Vovchenko Olha

DOI (article): https://doi.org/10.32626/2227-6246.2020-49.11-36 
ку, надзвичайно гостро постає проблема становлення такої особистості у підлітковому віці, їі соціальної адаптації та соціалізації. Профілактика й корекція проявів агресії - це одне з основних завдань у процесі соціальної інтеграції таких підлітків. Своєчасна психологічна діагностика та корекція дають змогу виявити й коригувати вже сформовані форми агресивної поведінки, створити умови для ефективної адаптації таких підлітків у соціумі. Водночас недостатня узгодженість методологічних позицій у забезпеченні формування емоційного інтелекту, саморегуляції агресивної поведінки особистості з порушеннями розумового розвитку детермінує низку невирішених у прикладному аспекті проблем розроблення ефективних технологій, по-перше, щодо діагностики явища, по-друге, щодо процесів формування та психолого-педагогічного супроводу означених аспектів проблеми.

Агресія - це психічний стан, який на певний час обумовлює ставлення до людини чи до інших об'єктів (живих або неживих) і характеризується акцентуаціями характеру, емоційним інтелектом і вольовим аспектом. Агресія проявляється як властивість особистості та виступає як мотиваційний чинник, внутрішне спонукання до здійснення агресивних дій й характеризується наявністю деструктивних тенденцій у стосунках з оточуючими. Агресія - це поведінковий прояв, що характеризується спрямованістю на виконання дій, які спричиняють шкоду (фізичну, моральну чи матеріальну) живим істотам або заподіяння шкоди неживим об'єктам. Часто агресія у підлітків із порушеннями розумового розвитку - це потреба, що виступає метою і мотивом поведінки як самостійна цінність.

Серед основних причин прояву агресії підлітків необхідно підкреслити особистісні риси (акцентуації характеру, тривожність), установки, систему цінностей. Важливим аспектом розуміння причин прояву агресії $є$ акцентуації характеру. За визначенням А. Лічко, акцентуації характеру (c) Vovchenko Olha

DOI (article): https://doi.org/10.32626/2227-6246.2020-49.11-36 
межовий варіант норми, за якого окремі риси характеру надмірно посилені. Через граничне посилення одних особистісних рис за рахунок інших підліток виявляється вразливим у разі потрапляння в ситуації чи оточення певного типу (Личко, 2010). Такими, що сприяють прояву агресивної поведінки підлітків, можуть бути астено-невротичний, гіпертимний, істероїдний, нестійкий, епілептоїдний типи акцентуацій характеру. Тип акцентуації вказує на слабкі сторони характеру підлітка, тим самим дозволяючи передбачати чинники, здатні викликати психогенні реакції, що ведуть до дезадаптації, а отже - відкриваються перспективи для психологічної профілактичної взаємодії.

Означені типи акцентуацій характеру проявляються не завжди чітко, тому що структура характеру підлітка є динамічною та змінюється у процесі виховання, самовиховання чи психокорекції. Однак дослідження підлітків із порушеннями розумового розвитку з метою визначення типу акцентуації характеру дає змогу виявляти та вчасно запобігати можливості прояву агресії, що робить такі дослідження надзвичайно актуальними. Визначення типу характеру підлітка сприяє успіху підібраної та проведеної психологічної корекції чи терапії. Крім того, дослідження акцентуацій особистості дозволяє дати оцінку деяким іншим особистісним особливостям підлітка - психологічній схильності до алкоголізму, наркоманії, проявів делінквентної поведінки тощо. Без знання характеру підлітка досить складно встановити сімейні проблеми, роль яких у розвитку інтелектуальних порушень підлітків надзвичайно велика, і шкільні проблеми, пов'язані зі спілкуванням між однолітками та вчителями. Наслідком такого незнання буває неправильне ставлення до них, неадекватні вимоги, а отже - взаємні непорозуміння та конфлікти, що супроводжуються з боку підлітків проявами агресії.

Ч. Кожалієва зазначає, що підліткам із порушеннями розумового розвитку характерні порушення інстинктів саC Vovchenko Olha DOI (article): https://doi.org/10.32626/2227-6246.2020-49.11-36 
мозбереження, які проявляються в двох протилежних формах поведінки: пасивно-оборонній (прагнення до уникання небезпечних і складних ситуацій, відповідальних рішень, процесу вибору чи прийняття рішення, ситуацій, де потрібен вольовий акт); активно-оборонній (опозиційна поведінка, що супроводжується реакціями протесту, різними проявами агресії тощо) (Кожалиева, 2003). Послаблення інстинкту самозбереження у таких підлітків проявляється в зниженні інтересу чи байдужості до життя, виникненні суїцидальних думок і вчинків. Перекручення інстинкту самозбереження виявляється в актах самокатування, аутоагресії, шрамуванні, проковтуванні металевих та інших предметів.

Воля та саморегуляція емоцій, на думку сучасних вітчизняних психологів Л. Кульчицької (Кульчицька, 2007), Д. Марченко (Марченко, 2010) i зарубіжних учених Дж. Мейсона (Mason, 2007), П. Мілфа (Milf, 2003), Г. Іркіда (Irkid, 2018), є рушійною силою, каталізатором процесів саморегуляції агресивної поведінки. У процесі емоційно-вольової саморегуляції воля виступає як дія, що проходить чотири етапи: 1) виникнення спонуки, бажання, мотиву або постановка попередньої мети; 2) боротьба мотивів; 3) прийняття рішення; 4) виконання. О. Бозуєва зазначає, що в ситуаціях реального функціонування особистості, залежно від умов, етапи матимуть різну тривалість і характер, інколи достатньо довго підліток зосереджується на одній фазі та швидко минає інші (Бозуєва, 2014). Д. Соколов підкреслює, що у підлітків із порушеннями розумового розвитку нерідко спостерігається друга фаза, а прийняття рішення має інстинктивний, рефлекторний характер. Часто третя і четверта фази відбуваються майже одночасно (Соколов, 2017).

Регулятивна функція волі у підлітків із порушеннями розумового розвитку також характеризується своєрідністю: нестійкістю поведінкових реакцій в емоційно напружених ситуаціях, відсутністю стійких мотивів, швидкою зміною бажань тощо. До основних утворень волі, що характеризу(c) Vovchenko Olha

DOI (article): https://doi.org/10.32626/2227-6246.2020-49.11-36 
ються порушеннями у підлітків означеної категорії, належать: цілеспрямованість, сміливість, наполегливість, рішучість, сила волі, здатність стримуватися (володіти собою у негативних ситуаціях).

Воля як компонент саморегуляції агресивної поведінки підлітків із порушеннями розумового розвитку - це «не лише уміння чогось забажати та досягти, але й уміння змусити себе відмовитися від чогось, коли це необхідно», зазначав А. Макаренко (Макаренко, 2016). Саме тому, на нашу думку, особливу увагу в розвитку саморегуляції агресивної поведінки підлітків із порушеннями розумового розвитку потрібно зосереджувати на формуванні узгодженості вольових рис із розумінням власних емоційних станів, формуванні у них емоційного інтелекту та розуміння межі «треба» та «хочу». У роботі з підлітком необхідно уникати байдужого ставлення до будь-якої діяльності, людей, оскільки будь-яка реакція важливіша за їі відсутність. Так, Г. Борщевська зазначає, що у підлітків із порушеннями розумового розвитку формується не лише вольовий аспект, а й співчуття, сенситивність та емпатія (Борщевська, 2009). Емоційно-вольова сфера підлітка з порушеннями розумового розвитку - це процес регуляції власних емоцій, почуттів, дій, вчинків і поведінки шляхом їх співставлення зі змістом життєвої ситуації.

Досліджуючи феномен підліткової агресії, не потрібно забувати про те, що агресія - явище соціальне, вона проявляє себе як форма поведінки, засвоєна у процесі соціального навчання. Загалом, підлітки з порушеннями розумового розвитку ізольовані від суспільства, обмежені в спілкуванні та позитивному прийнятті з боку суспільства (і це є великою проблемою), оскільки негативізм суспільство проявляє повною мірою. Агресивні реакції засвоюються та підтримуються шляхом особистої участі в ситуаціях прояву агресії, а також унаслідок пасивного спостереження за проявами агресії. Чим більшу роль відіграють ситуативні чинники, C Vovchenko Olha DOI (article): https://doi.org/10.32626/2227-6246.2020-49.11-36 
тим більшого значення набуває процес навчання агресивної поведінки, що носить, переважно, соціальний характер. Соціалізація індивіда, особливо емоційні стосунки, що складаються з батьками, впливають на те, чи виявить себе агресія як психологічна властивість у формі соціально негативної, девіантної поведінки.

Підкреслимо, що агресивність є необхідною детермінантою активного сучасного життя. Вона обумовлюе формування таких властивостей особистості, як наполегливість, ініціативність, завзятість у досягненні мети, подолання перешкод. Агресію можна розглядати і як біологічно доцільну форму поведінки, яка сприяє виживанню, адаптації та соціалізації. Для підлітків із порушеннями розумового розвитку виявлення зв'язку агресії з певними характерологічними особливостями дає змогу не пригнічувати агресію, а навчитися контролювати та скеровувати їі прояви на побудову свого активного життя.

Відтак, теоретичний аналіз виявлення причин, умов i чинників агресивної поведінки підлітків із порушеннями розумового розвитку дає змогу констатувати, що поряд із зовнішньо обумовленими чинниками, які впливають на формування різноманітних агресивних проявів у поведінці, вагомої ролі набуває встановлення внутрішніх чинників, які обумовлюють функціонування агресії й агресивної поведінки. Ми вважаємо, що такими чинниками є: наявність акцентуйованих особистісних рис, сформованість чи несформованість емоційного інтелекту, стан вольової сфери, зокрема їі мотиваційного і саморегуляційного аспектів, які вимагають деталізації й уточнення. Саме тому в подальшому дослідженні буде використано психодіагностичні заходи щодо виявлення специфіки акцентуацій характеру підлітків означеної категорії та вивчення агресивної поведінки, які дозволять нам установити окреслені тенденції і переконливо, на рівні емпіричного дослідження, довести або спростувати їх існування.

(c) Vovchenko Olha

DOI (article): https://doi.org/10.32626/2227-6246.2020-49.11-36 
Отже, метою статті є Ірунтовне дослідження проблеми проявів агресії у підлітків із порушеннями розумового розвитку в контексті формування та впливу емоційного інтелекту на агресивну поведінку таких підлітків.

\section{Завдання статті}

Відповідно до поставленої мети визначено такі завдання:

- установити особливості проявів агресії у підлітків із порушеннями розумового розвитку;

- визначити специфіку впливу емоційного інтелекту на саморегуляцію агресивної поведінки у підлітків із порушеннями розумового розвитку;

- охарактеризувати рекомендації щодо технології психологічного супроводу з формування саморегуляції агресивної поведінки підлітків із порушеннями розумового розвитку в контексті емоційного інтелекту.

\section{Методи та методики дослідження}

Для розв'язання окреслених завдань і забезпечення достовірності положень і висновків нами було використано загальнонаукові та специфічні методи дослідження. Серед них - теоретичні: дедуктивний - для системного опису явища, що досліджується; індуктивний - для встановлення закономірностей, систематизації; емпіричні: методи психодіагностики, що дали можливість визначити показники й рівні.

Психологічна діагностика стану агресивної поведінки та iii емоційної саморегуляції у підлітків із порушеннями розумового розвитку здійснена за допомогою методики «Опитувальник агресивності Басса - Дарки»; методики «Адаптований характерологічний опитувальник Леонгарда - Шмішека»; методики «Емоційний інтелект» (за Н. Холлом), бесіди.

Дослідженням було охоплено 108 підлітків із порушеннями розумового розвитку та 129 учнів зі збереженим інте-

(C) Vovchenko Olha

DOI (article): https://doi.org/10.32626/2227-6246.2020-49.11-36 
лектом (учні 5-9-х класів). Психодіагностика проводилася відповідно до інструкцій, із дотриманням необхідних вимог і використанням інструментарію на базі спеціальної загальноосвітньої школи-інтернату № 17, спеціальної загальноосвітньої школи-інтернату № 12 , загальноосвітньої школи № 149, загальноосвітньої школи № 64 (м. Київ).

\section{Результати та дискусії}

У зарубіжних дослідженнях в етико-гуманістичному підході однією з найпоширеніших теорій походження агресії $\mathrm{\epsilon}$ «поведінкова» модель, яку досліджував А. Басс і визначав її як будь-яку поведінку, що містить загрозу нанесення шкоди чи пряме нанесення шкоди іншим людям (Buss, 1961). Відповідно до цієї теорії, агресивна поведінка може бути класифікована за такими видами дій: фізична - вербальна; активна - пасивна, пряма - непряма (табл. 1).

\section{Таблиця 1}

Класифікація агресивних дій (за А. Бассом)

\begin{tabular}{|l|l|}
\hline \multicolumn{1}{|c|}{$\begin{array}{c}\text { Види } \\
\text { агресивних дій }\end{array}$} & \multicolumn{1}{|c|}{ Визначення } \\
\hline $\begin{array}{l}\text { Вербальна } \\
\text { агресія }\end{array}$ & $\begin{array}{l}\text { Форма агресивної поведінки, за якої вико- } \\
\text { ристовується відреагування своїх негативних } \\
\text { емоцій: за допомогою відповідних інтонацій } \\
\text { та інших невербальних компонентів мови; за } \\
\text { допомогою висловлювань загрозливого змісту }\end{array}$ \\
\hline Фізична агресія & $\begin{array}{l}\text { Агресивна поведінка з використанням фізич- } \\
\text { ної сили, що спрямовується проти іншого } \\
\text { суб'єкта чи об'єкта }\end{array}$ \\
\hline Непряма агресія & $\begin{array}{l}\text { Агресивна поведінка суб'єкта, спрямована } \\
\text { проти особи чи предмета, що не усвідомлю- } \\
\text { єтья чи приховується }\end{array}$ \\
\hline Пряма агресія & $\begin{array}{l}\text { Агресивна поведінка навмисного характеру, } \\
\text { мета якої не приховується }\end{array}$ \\
\hline
\end{tabular}

C Vovchenko Olha

DOI (article): https://doi.org/10.32626/2227-6246.2020-49.11-36 
Автор також здійснює якісну диференціацію виокремлених типів агресії за показниками «інструментальна агресія» та «ворожа агресія». Інструментальна агресія - це агресія як засіб досягнення певної мети. Ворожа агресія - це агресивна поведінка, орієнтована на заподіяння шкоди, болю і страждань іншій людині.

Відтак, за результатами методики «Опитувальник агресивності Басса - Дарки» у підлітків із порушеннями розумового розвитку виявлено фізичну (65\%) і вербальну агресію $(65 \%)$, що перевищує допустиму норму (рис. 1).

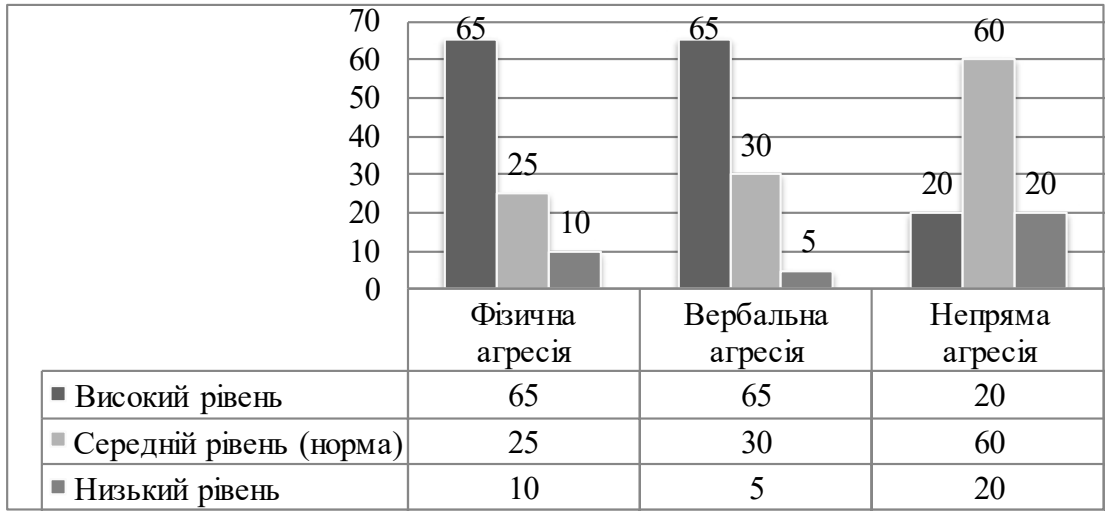

Puc. 1. Види прояву агресії підлітками з порушеннями розумового розвитку (у \%)

У переважної більшості підлітків (60\%) майже не діагностовано непряму агресію. Ї̈̈ показник знаходиться у межах допустимої норми та характеризується середнім рівнем. Підлітки із середнім рівнем непрямої агресії не схильні до накопичення таких почуттів та емоцій, як злість, злопам'ятство, помста через тривалий час. Негативні емоції вони виявляють миттєво, одразу після їх переживання, іноді не співвідносно з об’єктом, який викликав цю емоцію. Позитивним аспектом такої поведінки у досліджуваних підлітків є те, що негативна емоція не накопичується у струк-

(C) Vovchenko Olha

DOI (article): https://doi.org/10.32626/2227-6246.2020-49.11-36 
DOI: https://doi.org/10.32626/2227-6246.2020-49

турі особистості, але негативним аспектом є спосіб вивільнення такої агресії у підлітків із порушеннями розумового розвитку: хаотичність їі вираження, невпорядкованість, безвекторність і відсутність розуміння причин виникнення. Вираження афекту таким чином призводить до порушень комунікативної поведінки, соціальної адаптації підлітка серед однолітків і старших осіб.

Результати діагностики підлітків зі збереженим інтелектом констатують схожість отриманих даних щодо рівня вираженості основних видів агресивності з результатами підлітків із порушеннями розумового розвитку. Різниця полягає в інтенсивності прояву показника. У підлітків із порушеннями розумового розвитку показники яскравіше виражені в середньому на 20-30\%, ніж у підлітків без порушень інтелектуального розвитку.

Діагностика підлітків із порушеннями розумового розвитку дала змогу також констатувати стан функціонування структурних компонентів агресивності. Підвищений рівень було встановлено за показниками негативізму (75\%) і дратівливості - у 75\% обстежених підлітків (рис. 2).

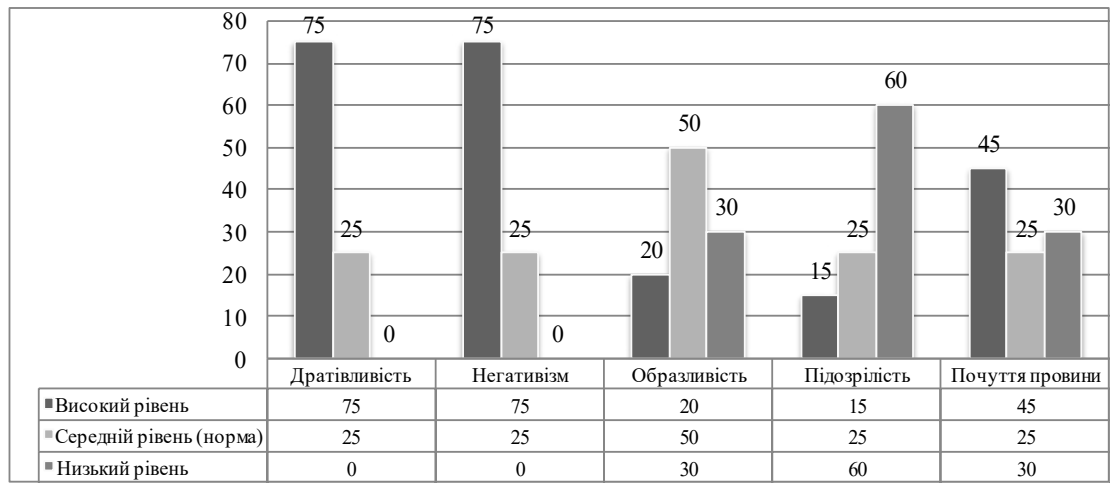

Puc. 2. Рівень функціонування компонентів агресивності у підлітків із порушеннями розумового розвитку (у \%) 
У $50 \%$ досліджуваних підлітків показник образливості не перевищує допустимої норми, а в 45\% - почуття провини характеризується високим показником. Це дає підстави констатувати, що підлітку властиве співчуття, він має достатній рівень емпатійної здатності та саморефлексії. Характерним для майже всіх продіагностованих підлітків із порушеннями розумового розвитку було заниження та низький рівень показника підозрілості. Можна припустити, що результати цього показника пов'язані з такою характеристикою розумово відсталих підлітків, як сугестивність.

У підлітків зі збереженим інтелектом компоненти агресивності характеризуються схожими результатами, але знов-таки різниця полягає в інтенсивності вираження. Згідно з отриманими результатами, у підлітків без порушень розумового розвитку менш виражена інтенсивність показників. Варто зазначити, що, на відміну від підлітків із порушеннями розумового розвитку, в підлітків зі збереженим інтелектом показник образливості має високий рівень (65\%). У підлітків із порушеннями розумового розвитку високим рівнем відзначено лише $20 \%$ досліджуваних. Різницю в результатах показників установлено за шкалою підозрілості. Підлітки зі збереженим інтелектом характеризуються вищим рівнем підозрілості $(40 \%)$, ніж підлітки з порушеннями розумового розвитку (15\%). Можна припустити, що це пов'язано зі здатністю підлітків зі збереженим інтелектом до самоаналізу, самокритичності, самонавіювання тощо.

За результатами діагностики підлітків із порушеннями розумового розвитку встановлено, що агресивність має конструктивний характер у переважної більшості означених підлітків (55\%). У 45\% діагностовано іï деструктивний характер (рис. 3). У підлітків зі збереженим інтелектом агресивність, як і у підлітків із порушеннями розумового розвитку, має переважно конструктивний характер (70\%), а в $30 \%$ - деструктивний. Конструктивний характер визначається проявом агресії лише у відповідь, як захист своїх

(C) Vovchenko Olha

DOI (article): https://doi.org/10.32626/2227-6246.2020-49.11-36 
DOI: https://doi.org/10.32626/2227-6246.2020-49

інтересів, реакція на образу чи порушення особистих кордонів безпеки. Аналізуючи гендерний аспект агресивності, було встановлено, що у хлопців із порушеннями розумового розвитку домінує фізична агресія та негативізм, у дівчат вербальна агресія та негативізм.

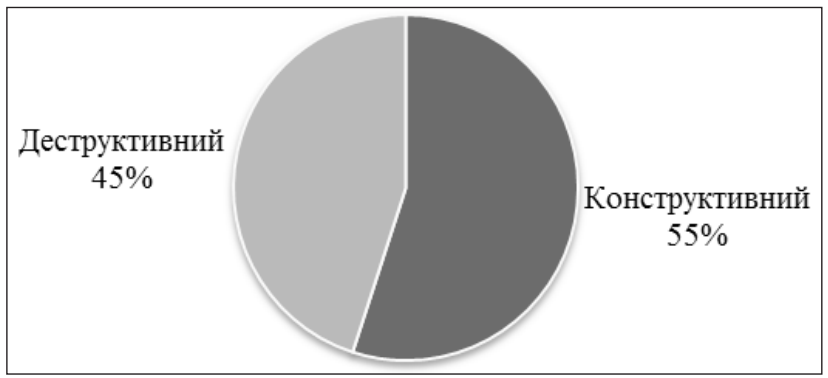

Puc. 3. Характер прояву агресії у підлітків із порушеннями розумового розвитку (у \%)

Крім того, варто відзначити специфіку поведінки підлітків із порушеннями розумового розвитку під час спостережень за ними у ході бесід, тестувань. Чим більша агресивність у підлітка на певний момент часу, тим менший за силою стимул необхідний для вияву їі назовні. У досліджуваних підлітків сила стимулу з навколишнього середовища не потребує інтенсивного каталізатора.

Наявність високого рівня агресивності впливає на соціальну адаптацію підлітка. Неконтрольовані прояви агресивності ускладнюють конструктивні взаємодії підлітка 3 порушеннями розумового розвитку з оточуючими у сфері суб’єктно-об’єктних відносин. Після прояву агресії для таких підлітків характерно прагнення, щоб його захистили, схвалили такий стиль поведінки, виправдали та сприйняли позитивно.

Причини агресивної поведінки у підлітків із порушеннями розумового розвитку можуть обумовлюватися гендерними особливостями. Так, хлопці з порушеннями розумово(c) Vovchenko Olha

DOI (article): https://doi.org/10.32626/2227-6246.2020-49.11-36 
го розвитку часто проявляють агресію як прояв реакції на примус - на відміну від агресії хлопців підліткового віку зі збереженим інтелектом, що характеризується підвищеною амбіційністю, максималізмом, низьким рівнем компромісності. Спільною ознакою для агресії у хлопців зі збереженим інтелектом і порушеннями розумового розвитку є прояв нарцисизму. Нарцисизм обумовлює прагнення підлітка до самоствердження в колективі однолітків за допомогою фізичної сили, брутальності, злих жартів тощо.

Прояви агресії та саморегуляція агресивної поведінки, як зазначено вище, детермінуються акцентуаціями особистості, що досліджені за методикою діагностики акцентуацій характеру Леонгарда - Шмішека «Характерологічний опитувальник». У підлітків із порушеннями розумового розвитку яскраво виражені три акцентуації: гіпертимна, циклотимічна та неврівноважена (табл. 2).

таблиця 2

Порівняльний аналіз типів акцентуації у підлітків із порушеннями розумового розвитку (у \%)

\begin{tabular}{|l|l|c|c|c|}
\hline \multicolumn{1}{|c|}{ Акцентуація } & \multicolumn{1}{|c|}{$\begin{array}{c}\text { Тип характеру } \\
\text { за Леонгардом }\end{array}$} & $\begin{array}{c}\text { Вира- } \\
\text { жена } \\
(\%)\end{array}$ & $\begin{array}{c}\text { При- } \\
\text { хована } \\
\text { (\%) }\end{array}$ & $\begin{array}{c}\text { Відсутня } \\
\text { (практич- } \\
\text { но відсут- } \\
\text { ня) (\%) }\end{array}$ \\
\hline \multicolumn{1}{|c|}{2} & \multicolumn{1}{|c|}{2} & 4 & 5 \\
\hline Гіпертимна & Гіпертимний & 66,7 & - & 33,3 \\
\hline Збудлива & $\begin{array}{l}\text { Застрягаючий, } \\
\text { ригідний }\end{array}$ & - & 50,0 & 50,0 \\
\hline Емотивна & Емотивний & 33,3 & 33,3 & 33,3 \\
\hline $\begin{array}{l}\text { Педантична } \\
\text { (дистимічна, } \\
\text { депресивна) }\end{array}$ & $\begin{array}{l}\text { Дистимічний, } \\
\text { педантичний }\end{array}$ & 16,7 & 33,3 & 50,0 \\
\hline $\begin{array}{l}\text { Тривожна } \\
\text { (невротична) }\end{array}$ & Тривожний & 16,7 & 33,3 & 50,0 \\
\hline Циклотимічна & Афективно-лабільний & 66,6 & 16,7 & 16,7 \\
\hline
\end{tabular}

(C) Vovchenko Olha

DOI (article): https://doi.org/10.32626/2227-6246.2020-49.11-36 
Продовження табл. 2

\begin{tabular}{|l|l|c|c|c|}
\hline \multicolumn{1}{|c|}{1} & \multicolumn{1}{|c|}{2} & 3 & 4 & 5 \\
\hline $\begin{array}{l}\text { Демонстративна } \\
\text { (витіснена) }\end{array}$ & Демонстративний & - & 66,7 & 33,3 \\
\hline $\begin{array}{l}\text { Неврівноважена } \\
\text { (параноїдальна) }\end{array}$ & $\begin{array}{l}\text { Неврівноважений, } \\
\text { застрягаючий }\end{array}$ & 66,6 & 16,7 & 16,7 \\
\hline Дистимна & Дистимний & - & 50,0 & 50,0 \\
\hline $\begin{array}{l}\text { Екзальтована } \\
\text { (інтроективна) }\end{array}$ & $\begin{array}{l}\text { Афективно- } \\
\text { екзальтований }\end{array}$ & 50,0 & - & 50,0 \\
\hline
\end{tabular}

У підлітків із порушеннями розумового розвитку констатовано такі основні типи поєднання акцентуацій: гіпертимна у поєднанні з циклотимічною (24\%); гіпертимна 3 неврівноваженою (26\%); гіпертимна з екзальтованою (17\% ). Домінування цих акцентуацій підкреслює психологічні особливості структури особистості підлітка 3 порушеннями розумового розвитку. Наприклад, поєднання гіпертимної 3 неврівноваженою акцентуацією у підлітка характеризується підвищеною динамічністю емоційних проявів, спонтанністю афектів, застряганням певних емоцій, гіперактивністю, низькою концентрацією уваги, непостійністю уподобань тощо. Такими підлітками легко маніпулювати. Позитивними характеристиками поєднання двох акцентуацій є принциповість і схильність до господарювання; негативними імпульсивність, непоміркованість поведінки, необов'язковість, ледарство, високий рівень роздратованості, спонтанність рішень - без обдумування, перебільшене ставлення до ситуацій. Підлітків із такою акцентуацією необхідно привчати до повільних та одноманітних дій, обговорення подій, що відбуваються у їхньому житті, з метою уникнення необдуманих вчинків.

Поєднання циклотимічної та гіпертимної акцентуацій свідчить про підлітка з нестійким настроєм, низьким рівнем прихильностей, різкою зміною емоційних станів без вагомих причин, низьким рівнем комунікабельності тощо. Такі (c) Vovchenko Olha

DOI (article): https://doi.org/10.32626/2227-6246.2020-49.11-36 
підлітки надають перевагу індивідуальним видам робіт, усамітненню.

Поєднання гіпертимної й екзальтованої акцентуацій констатує низький рівень здатності до диференціації емоцій, різку динаміку зміни полюсності емоційних станів (швидкість зміни позитивного стану на негативний), високу стомлюваність особистості, егоїстичність, високий рівень образливості, низький емоційний контроль і самоконтроль.

За результатами дослідження акцентуацій у підлітків зі збереженим інтелектом було встановлено схожість прояву акцентуацій. Так, домінантними є гіпертимна, емотивна, дистимна (педантична), тривожна та демонстративна.

У процесі діагностики підлітків із порушеннями розумового розвитку за методикою «Емоційний інтелект» (за Н. Холлом) було встановлено низький рівень емоційного інтелекту, емоційної обізнаності, емпатії, управління власними емоціями та середній рівень здатності до розпізнавання емоцій інших людей (рис. 4). За результатами діагностування жоден із показників не відзначався високим рівнем.

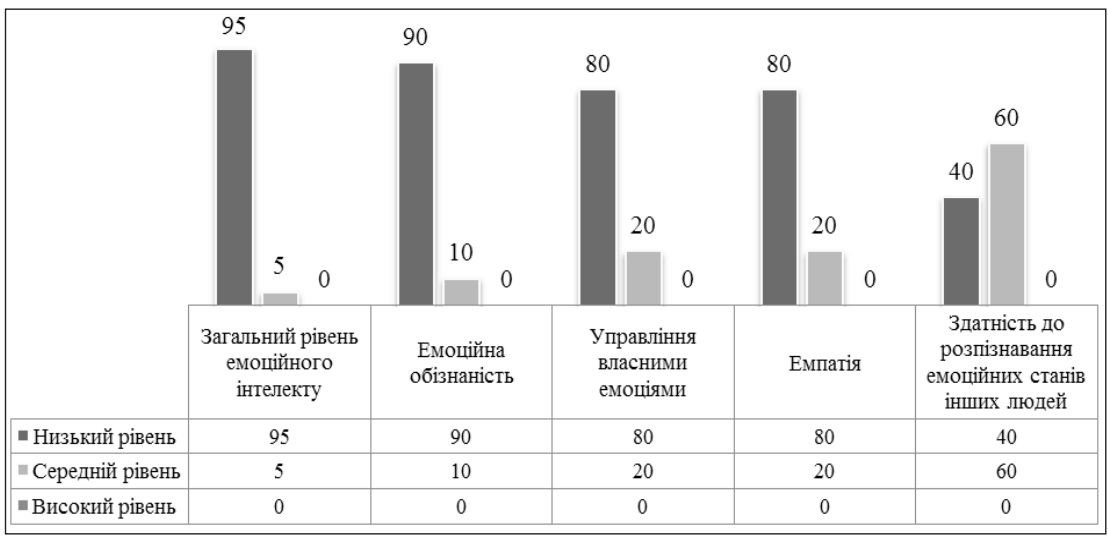

Puc. 4. Стан сформованості емоційного інтелекту та його складових у підлітків із порушеннями розумового розвитку за методикою Н. Холла «Емоційний інтелект» (у \%)

(C) Vovchenko Olha

DOI (article): https://doi.org/10.32626/2227-6246.2020-49.11-36 
DOI: https://doi.org/10.32626/2227-6246.2020-49

Із метою порівняльного аналізу стану сформованості емоційного інтелекту як показника саморегуляції агресивної поведінки підлітків із порушеннями розумового розвитку було проведено діагностування емоційного інтелекту в підлітків зі збереженим інтелектом. Отримані дані дають підстави констатувати, що для підлітків зі збереженим інтелектом властивий середній рівень загального показника емоційного інтелекту, емпатії, емоційної обізнаності, управління власними емоціями та здатності до розпізнавання емоцій інших людей.

Можна припустити, що низький показник за шкалою емоційного інтелекту та його складових у підлітків із порушеннями розумового розвитку детермінується не лише порушеннями інтелектуальної сфери, а водночас алекситимією, тобто станом, за якого не вистачає розуміння, здатності до аналізу й опису емоцій у собі, що підтверджує і низький показник емоційної усвідомленості. Алекситимія визначається як низький рівень розвитку афективних і когнітивних процесів. Вона часто характеризує інтелектуально слаборозвинуту особистість, яка відзначається низькою здатністю до опису свого власного емоційного стану, недостатньою диференціацією власних відчуттів та емоцій. Алекситимічні прояви у структурі особистості констатуються через невміння вербалізувати власні емоційні стани, недорозвиток рефлексивного компонента емоцій і несформованість або низький рівень емоційного інтелекту.

Провідною емоційною модальною характеристикою підлітків з алекситимією є емоція гніву (варіації та відтінки цієї емоції - роздратованість, злість тощо). Такі підлітки характеризуються низькою здатністю до адаптованості власних емоцій, тобто мають труднощі з адекватним вираженням емоцій відповідно до ситуації, що їх детермінує.

У підлітків із порушеннями розумового розвитку алекситимія проявляється у труднощах під час вираження емоцій і почуттів, у поведінці під час емоційно напружених (c) Vovchenko Olha

DOI (article): https://doi.org/10.32626/2227-6246.2020-49.11-36 
ситуацій, у нездатності пояснити, розповісти, що відбувається з підлітком у певний момент на рівні переживань. У досліджуваних підлітків алекситимія часто впливає на рівень сформованості образу «Я», що виражається через нездатність до вербалізації своїх власних емоційних переживань, емоцій оточуючих, низьку здатність до управління власними емоціями.

Беручи до уваги отримані результати, варто зазначити, що підлітки з порушеннями розумового розвитку потребують додаткових психокорекційних занять, що будуть спрямовані на формування вміння називати емоції, почуття, які вони переживають, означувати їх відповідними вербальними символами, а також занять, що навчатимуть підлітка управляти різними емоційними станами, зокрема негативними, як-то агресивність, злість, гнів.

\section{Висновки}

Варто підкреслити, що у підлітків із порушеннями розумового розвитку процес самопізнання внутрішніх психічних актів і станів слаборозвинений або взагалі відсутній. Про це свідчать низький рівень емоційного інтелекту, емоційної обізнаності, емпатії, управління власними емоціями та середній рівень здатності до розпізнавання емоцій інших людей. Також вагомим є встановлення алекситимічних особливостей у структурі особистості підлітка з порушеннями розумового розвитку. Такі підлітки характеризуються низькою здатністю до адаптованості власних емоцій, тобто мають труднощі з адекватним вираженням емоцій відповідно до ситуації, що їх детермінує, зокрема з проявом і контролем гніву, злості, люті, агресії тощо.

Відтак, на підставі діагностичних результатів акцентуації характеру, прояву агресивної поведінки підлітків із порушеннями розумового розвитку в різних системах взаємодії та на підставі аналізу особливостей сформованості емоційного інтелекту доцільним є розроблення програми упе-

(c) Vovchenko Olha

DOI (article): https://doi.org/10.32626/2227-6246.2020-49.11-36 
редження й корекції формування саморегуляції агресивної поведінки підлітків із порушеннями розумового розвитку.

Метою такої психокорекційної програми є, першою чергою, формування усвідомлення власної емоційної сфери підлітком із порушеннями розумового розвитку, розуміння такого поняття, як «агресивність» у поведінці, навчання підлітків керувати нею у процесі життєдіяльності, пошук альтернативних соціально прийнятних способів задоволення особистісних потреб. Основними завданнями такої програми мають бути:

- створення системи взаємодії практичного психолога з підлітком і сім'єю;

- усвідомлення, диференціація та вербалізація підлітком власних емоцій та емоційних станів;

- формування і розвиток здатності розуміти емоції й емоційні стани іншої людини, формування адекватної реакції;

- формування, усвідомлення та вербалізація власних потреб і мотивів діяльності та способи їх задоволення; формування адекватного образу «Я» підлітка;

- формування у підлітка самоконтролю за власними агресивними діями, емоціями й емоційними станами.

Психокорекційні заходи щодо формування саморегуляції агресивної поведінки підлітків із порушеннями розумового розвитку повинні реалізовуватися, по-перше, шляхом безпосереднього впливу на особистість підлітка з порушеннями розумового розвитку, по-друге, шляхом впливу на нього через його найближче оточення, сім'ю. Це надзвичайно важливі умови здійснення психокорекційної програми, оскільки, як зазначалося вище, підліток формується у соціумі, засвоюючи ті приклади поведінки, які бачить найчастіше, як стосовно себе, так і загалом навколо себе.

Доцільно зазначити, що важливим аспектом є запровадження не лише психокорекційної програми з підлітковою аудиторією, а й роз'яснювальна робота з батьками та педа(c) Vovchenko Olha

DOI (article): https://doi.org/10.32626/2227-6246.2020-49.11-36 
гогами про те, що таке агресія, які причини її появи, чим вона небезпечна, проведення тренінгів щодо навчання ефективним способам спілкування та взаємодії з підлітком, зміна засобів контролю поведінки на м'якші, навчання батьків володіти собою, своїми емоціями.

\section{Література}

Бозуєва О. Агресивність: причини, наслідки та контроль. Київ : Квіт, 2014. 206 c.

Борщевська Г. Воля та емоції у підлітків з порушеннями психофізичного розвитку: теоретико-методологічний аспект. Харків : Вид-во Інституту технологій та виробництва, 2009. 179 с.

Кожалиева Ч. Образ Я в структуре личности умственно отсталых подростков. Москва : МГУ, 2003. 144 с.

Кульчицька Л. Феноменологія акцентуацій у підлітковому віці. Київ : Вид-во НПУ ім. М. П. Драгоманова, 2007. 220 с.

Личко А. Психопатии и акцентуации характера у подростков. Санкт-Петербург : Речь, 2010. 256 с.

Макаренко А. Книга для родителей. Санкт-Петербург : Питер, 2016. $288 \mathrm{c}$.

Марченко Д. Агресивність та девіація у підлітковому віці. Львів : КнигоДрук, 2010. 191 с.

Соколов Д. Мотивація і воля: норма та патологія. Київ : ВВ Смарт, 2017. 132 c.

Buss, A. (1961). The Psychology of aggression. New York - London : Wiley and Sons. 295 p.

Irkid, G. (2018). Child aggression. New York : ETN. 286 p.

Mason, J. (2007). Childhood and aggression. Boston. 168 p.

Milf, P. (2003). Frustration and motivation: theory and research method. London. $234 \mathrm{p}$.

\section{References}

Bozuieva, O. (2014). Ahresyunist: prychyny, naslidky ta kontrol [Aggression: causes, consequences and control]. Kyiv : Kvit [in Ukrainian].

Borshchevska, H. (2009). Volia ta emotsii u pidlitkiv $z$ porushenniamy psykhofizychnoho rozvytku: teoretyko-metodolohichnyi aspekt [The will and emotions of adolescents with disorders of psychophysical development: a theoretical and methodological aspect]. Kharkiv : Vyd-vo Instytutu tekhnolohii ta vyrobnytstva [in Ukrainian].

(C) Vovchenko Olha

DOI (article): https://doi.org/10.32626/2227-6246.2020-49.11-36 
DOI: https://doi.org/10.32626/2227-6246.2020-49 2020. ВипУСК 49

Kozhaliieva, Ch. (2003). Obraz Ya v strukture lichnosti umstvenno otstalykh podrostkov [Image Me in the personality structure of mentally retarded teenagers ]. Moskva : MGU [in Russian].

Kulchytska, L. (2007). Fenomenolohiia aktsentuatsii u pidlitkovomu vitsi [Phenomenology of accentuation of teenagers]. Kyiv : Vyd-vo NPU im. M. P. Drahomanova [in Ukrainian].

Lichko, A. (2010). Psikhopatii $i$ aktsentuatsii kharaktera u podrostkov [Psychopathy and character accentuation in adolescents]. Sankt-Peterburg : Rech [in Russian].

Makarenko, A. (2016). Kniga dlia roditelei [Book for parents]. Sankt-Peterburg : Piter [in Russian].

Marchenko, D. (2010). Ahresyvnist ta deviatsiia u pidlitkovomu vitsi [Aggression and deviation at the adolescence]. Lviv : KnyhoDruk [in Ukrainian].

Sokolov, D. (2017). Motyvatsiia i volia: norma ta patolohiia [Motivation and will: norm and pathology]. Kyiv : VV Smart [in Ukrainian].

Buss, A. (1961). The Psychology of Aggression. New York - London.

Irkid, G. (2018). Child aggression. New York.

Mason, J. (2007). Childhood and aggression. Boston.

Milf, P. (2003). Frustration and motivation: theory and research method. London.

Вовченко Ольга. Вплив емоційного інтелекту на саморегуляцію агресивної поведінки підлітків із порушеннями розумового розвитку

\section{АНОТАЦІЯ}

Метою статmі $є$ дослідження проблеми проявів агресії у підлітків із порушеннями розумового розвитку в контексті формування та впливу емоційного інтелекту на агресивну поведінку таких підлітків. Мета дослідження забезпечувалася поетапним вирішенням основних завдань: 1) установити особливості проявів агресії у підлітків із порушеннями розумового розвитку; 2) визначити специфіку впливу емоційного інтелекту на саморегуляцію агресивної поведінки у підлітків із порушеннями розумового розвитку; 3) охарактеризувати рекомендації щодо технології психологічного супроводу з формування саморегуляції агресивної поведінки підлітків із порушеннями розумового розвитку в контексті емоційного інтелекту.

Методи. Для розв'язання окреслених завдань і забезпечення достовірності положень і висновків було використано дедуктивний та індукC Vovchenko Olha

DOI (article): https://doi.org/10.32626/2227-6246.2020-49.11-36 
тивний методи, метод психологічної діагностики, бесіди та спостереження. Психодіагностична процедура стану агресивної поведінки та їі емоційної саморегуляції у підлітків із порушеннями розумового розвитку здійснена за допомогою методики "Опитувальник агресивності Басса-Дарки»; методики "Адаптований характерологічний опитувальник Леонгарда - Шмішека»; методики “Емоційний інтелект» (за Н. Холлом); бесіди і спостережень. У ході психодіагностики було дотримано необхідних інструкцій і вимог для отримання достовірних результатів. Бесіди проводилися в навчальних закладах, де навчалися підлітки. Спостереження за поведінкою підлітків проходило у звичних для них умовах у процесі навчальної діяльності. 3 метою порівняльного аналізу феномену саморегуляції агресивної поведінки у підлітковому віці та достовірності результатів було також здійснено діагностику підлітків зі збереженим інтелектом, дотримуючись однакових процедур проведення, в однакових умовах, що були створені й для підлітків із порушеннями розумового розвитку.

Результати дослідження. За результатами діагностики у підлітків із порушеннями розумового розвитку виявлено фрізичну та вербальну агресію, що перевищує допустиму норму. Діагностика підлітків із порушеннями розумового розвитку дала змогу також констатувати стан функціонування структурних компонентів агресивності. Підвищений рівень було встановлено за показниками негативізму та дратівливості. Результати діагностики підлітків зі збереженим інтелектом констатують схожість отриманих даних щодо рівня вираженості основних видів агресивності та структурних компонентів явища, порівняно з результатами підлітків із порушеннями розумового розвитку. Різниця полягає в інтенсивності проявів показника. У підлітків із порушеннями розумового розвитку показники представлені більш виражено на 20-30\%, ніж у підлітків зі збереженою інтелектуальною функцією. Установлено, що прояви агресії та саморегуляція агресивної поведінки детермінуються акцентуаціями особистості. У підлітків із порушеннями розумового розвитку констатовано такі основні типи поєднання акцентуацій, як гіпертимна у поєднанні з циклотимічною, гіпертимна з неврівноваженою, гіпертимна з екзальтованою. Крім того, у підлітків із порушеннями розумового розвитку встановлено низький рівень емоційного інтелекту, емоційної обізнаності, емпатії, управління власними емоціями та середній рівень здатності до розпізнавання емоцій інших людей.

(C) Vovchenko Olha

DOI (article): https://doi.org/10.32626/2227-6246.2020-49.11-36 
Висновок. Отримані результати дали підстави висловити припущення щодо алекситимічних проявів у структурі особистості підлітків із порушеннями розумового розвитку, що переважно виявляються через невміння вербалізувати власні емоційні стани, недорозвиток рефлексивного компонента емоцій і несформованість або низький рівень емоційного інтелекту. Беручи до уваги отримані результати, було охарактеризовано основні аспекти психокорекційної роботи з підлітками з порушеннями розумового розвитку щодо формування саморегулячії агресивної поведінки. Означена психокорекційна робота повинна бути спрямована на формування вміння називати емочії, почуття, які переживають підлітки, означувати їх відповідними вербальними символами, на управління підлітком різними емоційними станами, зокрема негативними, як-то агресивність, злість, гнів.

Ключові слова: підлітковий вік, порушення розумового розвитку, акцентуація характеру, саморегуляція, агресія, агресивна поведінка, емоційний інтелект.

Вовченко Ольга. Влияние эмоционального интеллекта на саморегуляцию агрессивного поведения подростков с нарушениями умственного развития

\section{АННОТАЦИЯ}

Целью статьи является исследование проблемы проявления агрессии у подростков с нарушениями умственного развития в контексте формирования и влияния эмоционального интеллекта на агрессивное поведение таких подростков. Цель исследования обеспечивалась поэтапным решением основных задач: 1) установить особенности проявлений агрессии у подростков с нарушениями умственного развития; 2) определить специфику влияния эмоционального интеллекта на саморегуляцию агрессивного поведения у подростков с нарушениями умственного развития; 3) охарактеризовать рекомендации по технологии психологического сопровождения относительно формирования саморегуляции агрессивного поведения подростков с нарушениями умственного развития в контексте эмоционального интеллекта.

Методы. Для решения оосновных задач и обеспечения достоверности положений и выводов были использованы дедуктивный и индуктивный методы, метод психологической диагностики, беседы и наб(c) Vovchenko Olha

DOI (article): https://doi.org/10.32626/2227-6246.2020-49.11-36 
людения. Психодиагностическая прочедура состояния агрессивного поведения и его эмоциональной саморегуляции у подростков с нарушениями умственного развития была осуществлена с помощью методики "Опросник агрессивности Басса - Дарки»; методики «Адаптированный характерологический опросник Леонгарда - Шмишека»; методики «Эмоциональный интеллект» (по Н. Холлу); беседы и наблюдений. В ходе психодиагностики были соблюдены необходимые инструкции и требования для получения достоверных результатов. Беседы проводились в учебных заведениях, где учились подростки. Наблюдение за поведением подростков проходило в привычных для них условиях в прочессе учебной деятельности. С целью сравнительного анализа феномена саморегуляции агрессивного поведения в подростковом возрасте и достоверности результатов было также осуществлено диагностику подростков с сохранным интеллектом, следуя одинаковым процедурам проведения, в одинаковых условиях, которые были созданы ранее и для подростков с нарушениями умственного развития.

Результаты исследования. По результатам диагностики у подростков с нарушениями умственного развития выявлено физическую и вербальную агрессию, которая превышает допустимую норму. Диагностика подростков с нарушениями умственного развития позволила также констатировать состояние функционирования структурных компонентов агрессивности. Повышенный уровень был установлен по показателям негативизма и раздражительности. Результаты диагностики подростков с сохранным интеллектом дают возможность констатировать сходство полученных данных с различием лишь в уровне выраженности основных видов агрессивности и структурных компонентов явления, по сравнению с результатами подростков с нарушениями умственного развития. Разница заключается в интенсивности проявлений показателя. У подростков с нарушениями умственного развития показатели представлены более выражено на 20-30\%, чем у подростков с сохранной интеллектуальной функцией. Установлено, что проявления агрессии и саморегуляция агрессивного поведения детерминируются акцентуациями личности. У подростков с нарушениями умственного развития констатировано следующие основные типы сочетаний акцентуаций: гипертимная в сочетании с циклотимической, гипертимная с неуравновешенной, гипертимная с экзальтированной. Кроме того, у подростков с нарушениями умственного развития установлен низкий (C) Vovchenko Olha DOI (article): https://doi.org/10.32626/2227-6246.2020-49.11-36 
DOI: https://doi.org/10.32626/2227-6246.2020-49 2020. ВиПУСК 49

уровень эмоционального интеллекта, эмоциональной осведомленности, эмпатии, управления собственными эмоциями и средний уровень способности к распознаванию эмоций других людей.

Вывод. Полученные результаты позволили высказать предположение об алекситимических проявлениях в структуре личности подростков с нарушениями умственного развития, которые преимущественно проявляются в неумении вербализировать собственные эмоциональные состояния, недоразвитии рефлексивного компонента эмоций и несформированности или низком уровне эмоционального интеллекта. Принимая во внимание полученные результаты, было охарактеризовано основные аспекты психокоррекционной работы с подростками с нарушениями умственного развития по формированию саморегуляции агрессивного поведения. Данная психокоррекционная работа должна быть направлена на формирование умения называть эмоции, чувства, которые переживают подростки, определять их соответствующими вербальными символами, на управление подростком различными эмоциональными состояниями, в частности негативными, такими как агрессивность, злость, гнев.

Ключевые слова: подростковый возраст, нарушения умственного развития, акцентуация характера, саморегуляция, агрессия, агрессивное поведение, эмоциональный интеллект.

Original manuscript received April 23, 2020

Revised manuscript accepted May 29, 2020

C Vovchenko Olha

DOI (article): https://doi.org/10.32626/2227-6246.2020-49.11-36 http://journals.uran.ua/index.php/2227-6246 